\section{Improved Heteroduplex Detection of Single-base Substitutions in PCR-amplified DNA}

\section{A.V. Peeters and M.J. Kotze}

Department of Human Genetics, Faculty of Medicine, University of Stellenbosch, Tygerberg, 7505, South

Africa
The ability to detect mutations in individuals and the subsequent DNA diagnosis of genetic diseases are becoming increasingly important for the researcher and diagnostician. Single-base substitutions $(80-90 \%)$ can be detected by single-strand conformation polymorphism (SSCP) $^{(1)}$ or heteroduplex ${ }^{(2)}$ analysis of PCR-amplified DNA in polyacrylamide gels. Although both methods are simple, the SSCP method described earlier is used more frequently for mutation detection. ${ }^{(3)}$ A drawback of this method, however, is that different mutations may require specific conditions to be detected by SSCP analysis. Furthermore, reproducibility is compromised because minor variations in specific gel running conditions can decrease the difference in mobility among conformations, thus complicating unequivocal scoring of aberrations. On the other hand, variations in the gel running conditions have little or no effect on the visualization of aberrant heteroduplex bands (A.V. Peeters, unpubl.). PCR products can be loaded directly onto a gel for heteroduplex analysis, whereas an additional denaturation step is required for SSCP analysis. In a comparative study, White et al. ${ }^{(4)}$ reported detection of eight of nine mutations by heteroduplex analysis, whereas only one of these single-base mismatches could be detected by SSCP analysis. We attempted to further improve the mutation detection efficiency of the heteroduplex method by lowering the extent of cross-linking [percent crosslinking, polyacrylamide $(\% \mathrm{C})]$ in gels. In doing so, the resolving power and sensitivity of standard polyacrylamide gels were enhanced.

\section{MATERIALS AND METHODS}

Genomic DNA was extracted from blood samples of a normal control group and hypercholesterolemic patients, who were heterozygous for known point mutations $^{(5-11)}$ in the low-density lipoprotein receptor (LDLR) ${ }^{(12)}$ and apolipoprotein (apo) $\mathrm{B}^{(13)}$ genes, using a standard lysis method. ${ }^{(14)}$ DNA regions spanning the mutation sites were PCR amplified using exon-specific oligonucleotide primers (Table 1) as described previously. ${ }^{(5-8)}$

Visualization of the heteroduplex formation that occurred during PCR was compared on $5 \% \mathrm{C}$ and $1 \% \mathrm{C}$ polyacrylamide gels $(1 \mathrm{~mm} \times 15 \mathrm{~cm} \times 30 \mathrm{~cm})$. The
5\%C gel was made according to White et al. ${ }^{(4)}$ The low cross-linking (1\%C) $10 \%$ polyacrylamide gel was made from a $40 \%$ stock solution containing $40 \%$ acrylamide and $0.4 \% \quad N, N^{\prime}$-methylenebisacrylamide. Both gels were supplemented with $15 \%$ urea $^{(4)}$ and run in $0.6 \times$ TBE. Aliquots $(5-7 \mu \mathrm{l})$ of the different PCR products were mixed with an equal volume of loading buffer $(95 \%$ formamide, $10 \mathrm{~mm}$ EDTA, $0.05 \%$ bromophenol blue, $0.05 \%$ xylene cyanol) and run overnight at $150 \mathrm{~V}$ in a waterjacketed apparatus at room temperature $\left(<30^{\circ} \mathrm{C}\right)$. These running conditions were maintained until fragments had migrated at least $25 \mathrm{~cm}$. The gel was then stained with ethidium bromide and photographed under ultraviolet light.

\section{RESULTS AND DISCUSSION}

Previously identified point mutations in the LDLR and apo B genes (Table 1) were used to determine whether increased sensitivity of heteroduplex analysis can be achieved by using low percentage cross-linked polyacrylamide gels. Although different acrylamide/bisacrylamide ratios have been described for optimal detection of specific mutations using SSCP analysis, ${ }^{(15)}$ this is the first application in heteroduplex analysis.

Figure 1 compares the efficiency of detecting heteroduplex formation in patients heterozygous for seven different single-base substitutions (lanes 2,3,5,7) on $5 \% \mathrm{C}(\mathrm{A}, \mathrm{C})$ and $1 \% \mathrm{C}(\mathrm{B}, \mathrm{D})$ polyacrylamide gels. PCR product from a normal control was loaded in lanes 1,4 , and 6 . In Figure $1 \mathrm{~A}$, the relatively large 428 - and 345-bp PCR products of the LDLR and apo B genes, respectively, appear as smears on a $5 \% \mathrm{C}$ polyacrylamide gel, making it impossible to distinguish the heteroduplex bands in lanes $2\left(\mathrm{C}_{2054^{-}} \mathrm{T}\right)$, $3\left(\mathrm{C}_{1959}-\mathrm{T}\right)$, and $5\left(\mathrm{G}_{10708} \mathrm{~A}\right)$ from the homoduplex bands. However, when equal amounts from the same PCR products were electrophoresed the same distance under identical conditions on a 1\%C polyacrylamide gel, heteroduplex formation could be observed in patients heterozygous for the three different point mutations (Fig. 1B). Analysis of LDLR gene fragments of 234 and 215 bp on a $5 \% \mathrm{C}$ polyacrylamide gel enabled detection of distinct heteroduplex bands in only two of the four point mutations tested (Fig. 1C). In the low cross-linking gel (Fig. 1D) all four mutations $\left(\mathrm{C}_{681}-\mathrm{G}\right.$, 
TABLE 1 Point Mutations in the LDLR and apo B Genes Analyzed by Heteroduplex Analysis of PCR-amplified DNA in 1\%C and 5\%C Polyacrylamide Gels

\begin{tabular}{|c|c|c|c|c|}
\hline Mutation & $\begin{array}{l}\text { Exon/ } \\
\text { intron }\end{array}$ & $\begin{array}{l}5^{\prime} \text { PCR primer }\left(5^{\prime} \rightarrow 3^{\prime}\right)^{*} \\
3^{\prime} \text { PCR primer }\left(5^{\prime} \rightarrow 3^{\prime}\right)\end{array}$ & $\begin{array}{l}\text { Fragment } \\
\text { size (bp) }\end{array}$ & Reference \\
\hline \multicolumn{5}{|l|}{ LDLR gene } \\
\hline $\mathrm{G}_{324}-\mathrm{T}$ & 4 & $\begin{array}{l}\text { CATCCATCCCTGCAGCCCCC }^{*} \\
\text { GGGGTCGTTGTCGCAGGCCC }\end{array}$ & 215 & 5 \\
\hline $\mathrm{C}_{681^{-}-\mathrm{G}}$ & 4 & $\begin{array}{l}\text { CGACTGCGAAGATGGCTCGGA* } \\
\text { GGGACCCAGGGACAGGTGATAGGAC }\end{array}$ & 234 & 6 \\
\hline $\mathrm{G}_{682}-\mathrm{A}$ & 4 & $\begin{array}{l}\text { CGACTGCGAAGATGGCTCGGA* } \\
\text { GGGACCCAGGGACAGGTGATAGGAC }\end{array}$ & 234 & 7 \\
\hline $\mathrm{G}-\mathrm{C}$ & 7 & $\begin{array}{l}\text { GGCGAAGGGATGGGTAGGGG* }^{*} \\
\text { GTTGCCATGTCAGGAAGCGC }\end{array}$ & 234 & 8 \\
\hline $\mathrm{C}_{1959-\mathrm{T}}$ & 13 & $\begin{array}{l}\text { GACAAAGTATTTTGGACAGA* } \\
\text { CTGTGAGGCAGCTCCTCATG }\end{array}$ & 428 & 9 \\
\hline $\mathrm{C}_{2054}-\mathrm{T}$ & 14 & $\begin{array}{l}\text { GACAAAGTATTTTGGACAGA* } \\
\text { CTGTGAGGCAGCTCCTCATG }\end{array}$ & 428 & 10 \\
\hline apo B gene & & & & \\
\hline$G_{10708}-A$ & 26 & $\begin{array}{l}\text { GGAGCAGTTGACCACAAGCTTAGC }{ }^{\star} \\
\text { CAGGGTGGCTTTGCTTGTATGTTC }\end{array}$ & 345 & 11 \\
\hline
\end{tabular}

(*)Upstream amplification primer.

lane 2; $\mathrm{G}_{682}-\mathrm{A}$, lane $3 ; \mathrm{G}_{324} \mathrm{~T}$, lane 5; $\mathrm{G}-\mathrm{C}$, lane 7) could be detected, and the difference in mobility between heteroduplex and homoduplex bands was

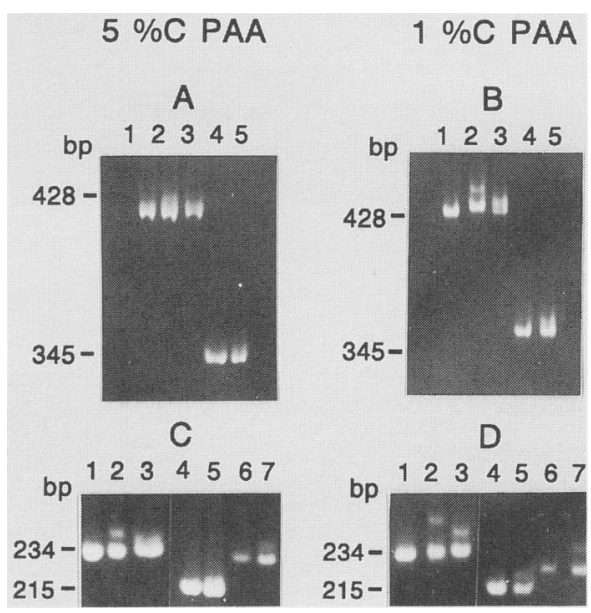

FIGURE 1 Heteroduplex analysis of seven known point mutations in the LDLR and apo $B$ genes. PCR products of 428 and $345 \mathrm{bp}$ $(A, B)$, and 234 and 215 bp $(C, D)$, were electrophoresed under identical conditions on $5 \% \mathrm{C}$ $(A, C)$ and $1 \% \mathrm{C}(B, D)$ polyacrylamide gels. PCR products from a mutation-negative control were loaded in lanes 1,4 , and 6 . Relatively large PCR products from patients heterozygous for the $\mathrm{C}_{2054^{-}} \mathrm{T}, \mathrm{C}_{1959^{-}} \mathrm{T}$, and $\mathrm{G}_{10708^{-}} \mathrm{A}$ mutations were loaded in lanes 2,3 , and 5 , respectively $(A, B)$, whereas smaller PCR products from patients heterozygous for the $C_{681^{-}}$$\mathrm{G}, \mathrm{G}_{682}-\mathrm{A}, \mathrm{G}_{324}-\mathrm{T}$, and G-C mutations were loaded in lanes $2,3,5$, and 7 , respectively $(C, D)$. greater. The same improved results can be obtained on Hydrolink-MDE gels (AT Biochem, Malvern, PA) supplemented with $15 \%$ urea (data not shown), but at a much higher cost.

We used only seven mutations ${ }^{(5-11)}$ in five different DNA fragments in the above comparisons, and it remains to be investigated as to how valuable this approach is in improving detection of single-base changes. Three single-base substitutions $^{(16,17)}$ analyzed did not show heteroduplex formation in any of the gel systems tested, although abnormal SSCP patterns could be observed after denaturation of PCR products and electrophoresis under specific conditions in nondenaturing polyacrylamide gels (data not shown). The opposite was, however, observed by White et al., ${ }^{(4)}$ where the majority of mutations were only detectable by heteroduplex analysis and not by SSCP analysis. The heteroduplex method detects mutations on the basis of a different principle than that of SSCP, and a combined approach of testing the same PCR product on both types of electrophoresis systems is highly sensitive. The ability to detect a specific mutation by SSCP and/or heteroduplex analysis is largely dependent on the sequence of the relevant DNA fragment, ${ }^{(1,4)}$ whereas lowering the extent of cross-linking in standard polyacrylamide gels improves visualization of aberrant bands after electrophoresis.

We thus conclude that low cross-link- ing polyacrylamide gels are highly sensitive in detecting single-base substitutions as heteroduplexes (and/or SSCPs). They also provide a less expensive alternative to Hydrolink-MDE gels for high resolution analysis.

\section{ACKNOWLEDGMENTS}

We thank J. Brusnicky for critical reading of this manuscript. This work was supported by the South African Medical Research Council and the University of Stellenbosch.

\section{REFERENCES}

1. Orita, M., Y. Suzuki, T. Sekiya, and K. Hayashi. 1989. Rapid and sensitive detection of point mutations and DNA polymorphisms using the polymerase chain reaction. Genomics 5: 874-879.

2. Keen, J., D. Lester, C. Inglehearn, A. Curtis, and S. Bhattacharya. 1991. Rapid detection of single base mismatches as heteroduplexes on Hydrolink gels. Trends Genet. 7: 5.

3. Cotton, R.G.H. 1993. Current methods of mutation detection. Mutat. Res. 285: 125-144.

4. White, M.B., M. Carvalho, D. Derse, S.J. O'Brien, and M. Dean. 1992. Detecting single base substitutions as heteroduplex polymorphisms. Genomics 12: 301-306.

5. Peeters, A.V., L.F. Van Gaal, and M.J. Kotze. 1994. A rare silent $\mathrm{G}$ to $\mathrm{T}$ mutation in exon 4 of the human low density lipoprotein receptor gene. Clin. Genet. (in press).

6. Kotze, M.J., L. Warnich, E. Langenhoven, L. du Plessis, and A.E. Retief. 1990. An exon 4 mutation identified in the majority of South African familial hypercholesterolemics. J. Med. Genet. 27: 298-302.

7. Leitersdorf, E., E.J. Tobin, J. Davignon, and H.H. Hobbs. 1990. Common lowdensity lipoprotein receptor mutations in the French Canadian population. J. Clin. Invest. 85: 1014-1023.

8. Jensen, L.G., H.K. Jensen, M. Kjeldsen, L.U. Gerdes, P.S. Hansen, O. Faergeman, S. Kolvraa, L. Bolund, and N. Gregersen. 1994. A new, highly informative SmaI polymorphism in intron 7 of the low density lipoprotein receptor (LDLR) gene. Clin. Genet. 45: 52-53.

9. Hobbs, H.H., V. Esser, and D.W. Russell. 1987. AvalI polymorphism in the human LDL receptor gene. Nucleic Acids Res. 15: 379 .

10. Soutar, A.K., B.L. Knight, and D.D. Patel. 1989. Identification of a point mutation in growth factor repeat $C$ of the low density lipoprotein receptor gene in a patient with homozygous familial hypercholeste- 
rolemia that affects ligand binding and intracellular movement of receptors. Proc. Natl. Acad. Sci. 86: 4166-4170.

11. Soria, L.F., E.H. Ludwig, H.R.G. Clarke, G.L. Vega, S.M. Grundy, and B.J. McCarthy. 1989. Association between a specific apolipoprotein B mutation and familial defective apolipoprotein B-100. Proc. Natl. Acad. Sci. 86: 587-591.

12. Yamamoto, T., C.G. Davis, M.S. Brown, W.J. Schneider, M.L. Casey, J.L. Goldstein, and D.W. Russell. 1984. The human LDL receptor: A cysteine-rich protein with multiple Alu sequences in its mRNA. Cell 39: 27-38.

13. Cladaras, C., M. Hadzopoulou-Cladaras, R.T. Nolte, D. Atkinson, and V. Zannis. 1986. The complete sequence and structural analysis of human apolipoprotein B-100: Relationship between apoB-100 and apoB-48 forms. $E M B O ~ J$. 5: 34953507.

14. Miller, S.A., D.D. Dykes, and H.F. Polesky. 1988. A simple salting out procedure for extracting DNA from human nucleated cells. Nucleic Acids Res. 16: 1215.

15. Savov, A., D. Angelicheva, A. Jordanova, A. Eigel, and L. Kalaydjieva. 1992. High percentage acrylamide gels improve resolution in SSCP analysis. Nucleic Acids Res. 20: $6741-6742$.

16. Kotze, M.J., E. Langenhoven, L. Warnich, L. du Plessis, M.P. Marx, C.J.J. Oosthuizen, and A.E. Retief. 1989. The identification of two low-density lipoprotein receptor gene mutations in South African familial hypercholesterolemia. S. Afr. Med. J. 76: 399-401.

17. Kotze, M.J., A.E. Retief, P.A. Brink, and H.F.H. Weich. 1986. A DNA polymorphism in the human low density lipoprotein receptor gene. S. Afr. Med. J. 70: 7779.

Received July 27, 1994; accepted in revised form September 13, 1994. 


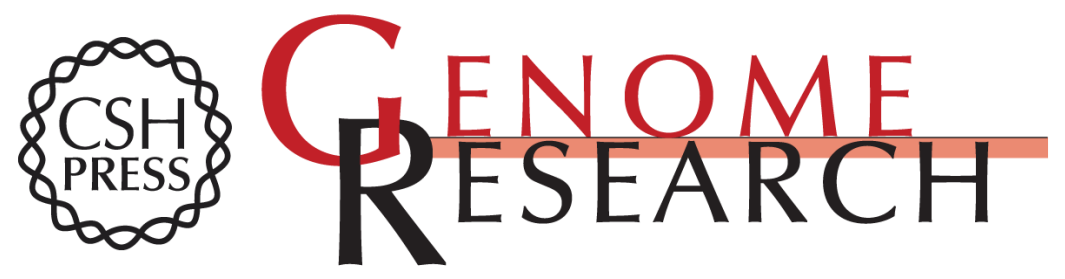

\section{Improved heteroduplex detection of single-base substitutions in PCR-amplified DNA.}

A V Peeters and M J Kotze

Genome Res. 1994 4: 188-190

References This article cites 16 articles, 3 of which can be accessed free at:

http://genome.cshlp.org/content/4/3/188.full.html\#ref-list-1

License

Email Alerting

Receive free email alerts when new articles cite this article - sign up in the box at the Service top right corner of the article or click here.

\section{Affordable, Accurate Sequencing.}

To subscribe to Genome Research go to: https://genome.cshlp.org/subscriptions 